\title{
Non-Healing Ulcer Due to Bone Wax in Alveolar Bone Graft Donor Site- A Case Report
}

\section{Alveoler Kemik Grefti Donör Sahasındaki Kemik Balmumu Nedeniyle Iyileşmeyen Ülser - Bir Olgu Sunumu}

Moumita De ${ }^{1}$, Rakesh Dawar ${ }^{1}$, Maneesh Singhal ${ }^{1}$, Ashish Bichpuriya ${ }^{1}$, Ravikiran Nalla ${ }^{1}$

${ }^{1}$ All India Institute of Medical Sciences

Geliş Tarihi/Received: 21 May 2019

Address correspondence to: Rakesh Dawar, Department of Plastic Reconstructive and Burns Surgery, Room no- 5014C, 5th floor, Teaching Block, All India Institute of Medical Sciences, New Delhi- 110029, India.

E-mail: rakeshdawar50@gmail.com

ORCID

Rakesh Dawar

https://orcid.org/0000000209511857 Ansari Nagar East, New Delhi, India Kabul Tarihi/Accepted: 10 July 2019

Öz
Kemik balmumu, balmumundan üretilmiş yaygın olarak kullanılan bir hemostatik ajandır. Nöroşirürji,
ortopedik cerrahi, çene ve ortognatik ameliyatlarda yaygın olarak kullanılır. Her ne kadar kemik balmumu
nedeniyle komplikasyon ile ilgili birkaç vaka bildirilmiş olmasına karşın, çeşitli cerrahi bölgelerde kullanımı
devam etmektedir. Alveoler kemik greftlenmesi için kemik kemik grefti yerleştildikten bir yıl sonra ortaya
çıkan iliak krest üzerinde olağandışı bir iyileşmeyen ülser vakasını sunuyoruz.
Anahtar Kelimeler: İyileşmeyen ülser, kemik balmumu, alveolar kemik grefti
Abstract
Bone wax is a commonly used hemostatic agent derived from beeswax. It is used widely in neurosurgery,
orthopaedic surgery, maxillofacial and orthognathic surgery. Although few case reports have emerged
regarding complication due to the bone wax, the use of it continues in various surgical sites. We report
an unusual case of a non-healing ulcer over the iliac crest appearing one year after bone harvest was
done for alveolar bone grafting.
Keywords: Non-healing ulcer, bone wax, alveolar bone graft

\section{INTRODUCTION}

Bone wax is a commonly used hemostatic agent derived from beeswax. It contains beeswax softened with isopropyl palmitate or paraffin. It is non absorbable and virtually stays for ever. It is used widely in neurosurgery, orthopaedic surgery, maxillofacial and orthognathic surgery. Although few case reports have emerged regarding complication due to the bone wax, the use of it continues in various surgical sites (1-3). We report an unusual case of a non-healing ulcer over the iliac crest appearing one year after bone harvest was done for alveolar bone grafting.

\section{CASE}

A sixteen year old girl with left sided group 3
Cleft Lip and Palate was operated one year back for alveolar cleft. Cancellous bone graft harvested from left iliac crest was used to fill up the alveolar defect. Post surgery patient recovered well and was discharged in a stable condition. Patient was on regular follow up in the orthodontics department and stopped following up with Plastic Surgery department after 3 months post-operatively. However, patient was referred to us after one year of surgery for an ulcer over the previous alveolar graft donor site. Patient gave a history of appearance of small ulcer over the donor site which gradually grew over 1 week. There was mild serous discharge from the ulcer. She was prescribed a course of antibiotics and managed with dressing. However, the ulcer failed to show any improvement over the next 3 weeks; hence decision

Cite this article as: Moumita $D$, Rakesh $D$, Maneesh $S$, Ashish $B$ 


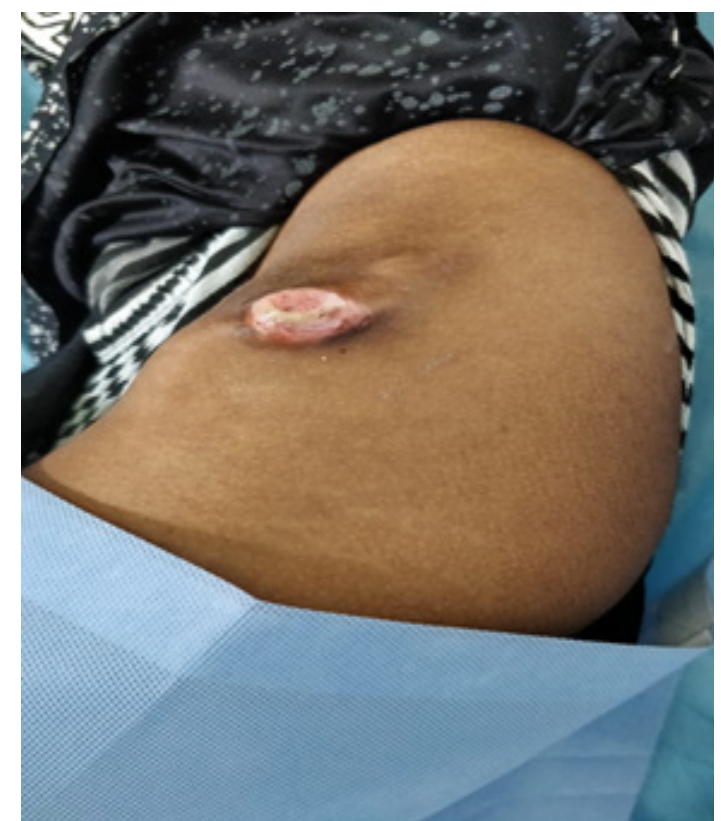

Figure 1. Non-healing ulcer left iliac crest

to operate was taken.

Under local anaesthesia, the ulcer was delineated. It was found connected to the underlying iliac crest. On exploration, fragments of whitish brittle material were found encased in unhealthy granulation tissue. The fragments were identified as bone wax used in the primary surgery. The ulcer was excised

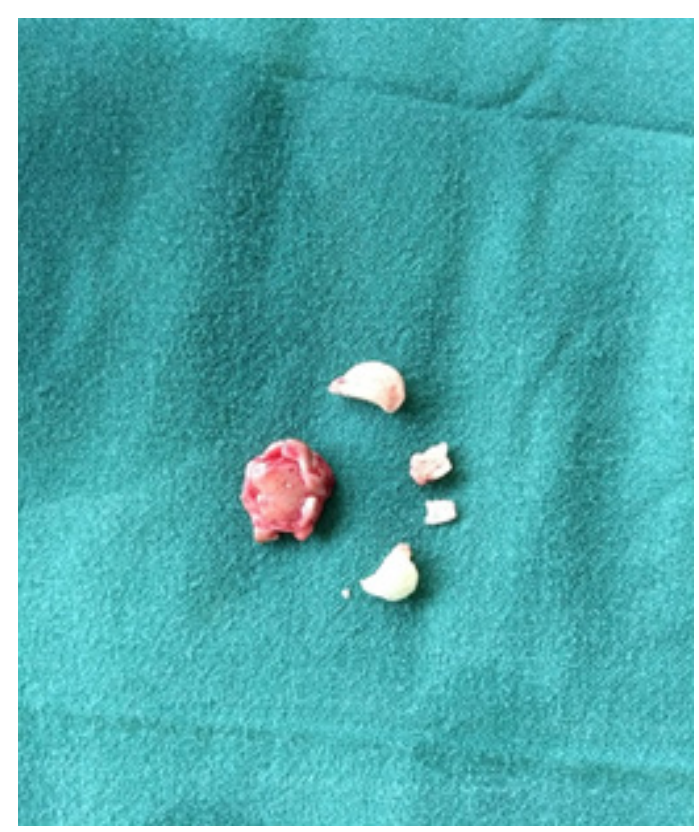

Figure 2. Specimen of excised ulcer with fragments of wax

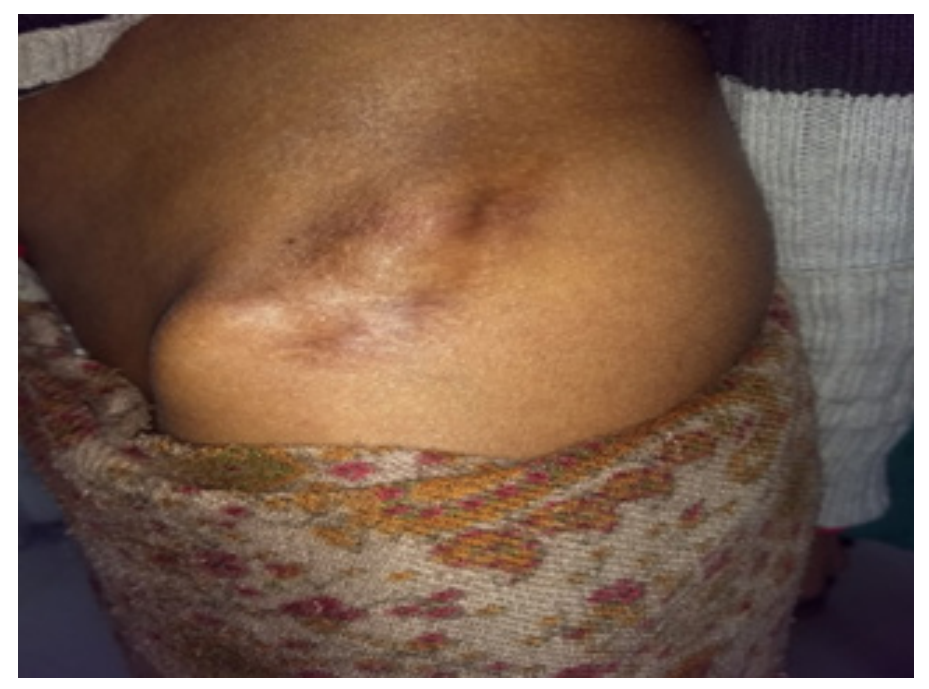

Figure 3. Wound site at 8 month follow-up

completely along with all unhealthy granulation tissue and remnants of bone wax. Thorough lavage of wound given and wound was closed primarily after mobilisation.

Post operatively, patient was prescribed 5 days of oral antibiotic and was discharged. The sutures were removed on 7th post-operative day. The wound healed satisfactorily. Now, on follow up after 8 months, patient has no further complaint.

\section{DISCUSSION}

Bone wax was developed by Horsley for hemostasis after surgeries of the bone. For maxillofacial and orthognathicsurgery, extraoral sites forboneharvesting are chosen such as iliac crest, parietal bone, fibula, rib. However, numerous studies have concluded over time that iliac crest bone graft can be considered a gold standard for large amount of cortico-cancellous bone harvest (1). In cleft surgery, iliac crest bone graft is widely used to fill up the alveolar cleft. Swan et al. (2) have studied the complications following iliac crest bone harvest in 72 patients with a minimum 18 months follow up. They have mentioned an infection rate of $3 \%$ in the donor area all of which was treated with oral antibiotics without further complications. Their reported incidence of pain at the donor site was $7 \%$ which resolved within 6 months. They reported no serious complication and no need for any re-operation in their series (2). There has been reported cases of extrusion of bone wax from the mastoid (3), foreign body granuloma formation in the calvarial donor site (4), in the orbit (5), and in the sternotomy wound as 
found in autopsy of 18 patients by Sudmann et al. (6) Persistent pain in the foot due to bone wax after surgery was reported by Anfinsen et al in 7 cases (7). However, few reports exist on iliac crest donor site complication due to bone wax. Qayum and Koka (8) reported a single case of persistent serous discharge from the donor site in the early post- operative period which improved after debridement and curettage of the wax used in previous surgery. De Riu et al. (9) reported a case of an abscess presenting 4 years after primary surgery at the iliac crest donor site. Although they postulated that chronic granulomatus inflammation due to bone wax was the probable cause of such delayed complication, they could not isolate any wax from the abscess cavity hence no conclusive proof (9). In our case, the delayed presentation after 1 year and the definite finding of wax fragments extruding through the ulcer is a conclusive proof that bone wax can give rise to delayed complications like non-healing ulcer due to slow, undulating chronic inflammatory pathology.

\section{CONCLUSION}

Bone wax, being a non-absorbable foreign material can give rise to complications. Therefore its use should be minimal and in a very controlled way. Although it is rare, any chronic wound of bone graft donor site should be kept in mind for such probable complication.

Conflict of interest: Authors declare that there is no conflict of interest between the authors of the article.

Financial conflict of interest: Authors declare that they did not receive any financial support in this study.
Address correspondence to: Rakesh Dawar, Department of Plastic Reconstructive and Burns Surgery, Room no- 5014C, 5th floor, Teaching Block, All India Institute of Medical Sciences, New Delhi- 110029, India.

Mobile number: +91- 9340369809

E-mail: rakeshdawar50@gmail.com

\section{REFERENCES}

1. Canady JW, Zeither D, Thompson S, et al. Suitability of the iliac crest as a site for harvest of autogenous bone grafts. Cleft Palate Craniofac J 1993:30:579-81.

2. Swan MC, Goodacre TEE. Morbidity at the iliac crest donor site following bone grafting of the cleft alveolus. Brit $\mathrm{J}$ Oral Maxillofac Surg 2006:44:129-33.

3. Baird SM, Teh BM, Lim KKM, et al. Bone wax extrusion through postauricular wounds: A case series. Laryngoscope 2018;128(2):369-72.

4. Wolvius EB, van der Wal KG. Bone wax as a cause of a foreign body granuloma in a cranial defect: A case report. Int J Oral Maxillofac Surg 2003;32(6):656-8.

5. Katz SE, Rootman J. Adverse effects of bone wax in surgery of the orbit. Ophthalmic Plast Reconstr Surg 1996;12(2):1216

6. Sudmann B, Bang G, Sudmann E. Histologically verified bone wax (beeswax) granuloma after median sternotomy in 17 of 18 autopsy cases. Pathology 2006:38:138-41.

7. Anfinsen OG, Sudmann B, Rait M, et al. Complications secondary to the use of standard bone wax in seven patients. J Foot Ankle Surg 1993;32(5):505-8.

8. Qayum A, Koka AH. Foreign body reaction to bone wax an unusual cause of persistent serous discharge from iliac crest graft donor site and the possible means to avoid such complication - a case report. Cases J 2009 27;2:9097.

9. De Riu G, Meloni SM, Raho MT, et al. Delayed iliac abscess as an unusual complication of an iliac bone graft in an orthognathic case. Int J Oral Maxillofac Surg 2008;37(12):1156-8 